\title{
The clinical significance of circulating tumor cells in gastrointestinal cancer
}

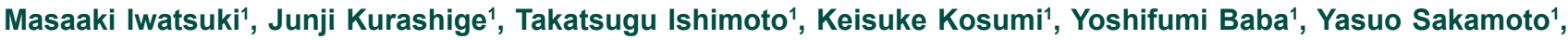
Yuji Miyamoto', Naoya Yoshida', Masayuki Watanabe ${ }^{2}$, Hideo Baba1

${ }^{1}$ Department of Gastroenterological Surgery, Graduate School of Medical Sciences, Kumamoto University, 1-1-1 Honjo, Chuo-ku, Kumamoto 860-8556, Japan.

${ }^{2}$ Department of Gastroenterological Surgery, Esophageal Cancer Division, Cancer Institute Hospital of Japanese Foundation for Cancer Research, 3-8-31 Ariake, Koto-ku, Tokyo 135-8550, Japan.

Correspondence to: Dr. Hideo Baba, Department of Gastroenterological Surgery, Graduate School of Medical Sciences, Kumamoto University, 1-1-1 Honjo, Chuo-ku, Kumamoto 860-8556, Japan. E-mail: hdobaba@kumamoto-u.ac.jp

\section{A B S T R A C T}

Circulating tumor cells (CTCs) are originated from the primary tumor lesion into the blood stream. CTCs could lead to recurrence of gastrointestinal (GI) cancers, even after a curative resection and colonizing in the distant organs to facilitate tumor distant metastasis; however, it has been challenging in clinic to detect CTCs for a long time, such as detection methodology or molecular markers for identification of CTCs. This review discussed the recent technical advances and biomarkers in the detection of CTCs and the molecular mechanism of CTC in cancer progression and metastasis. Moreover, novel concepts, such as cancer stem cells and epithelial-mesenchymal transition, could lead to CTCs and tumor progression and metastasis. Nevertheless, the involvement of CTCs varies greatly among cancer types in the GI and much remains to be learned. Thus, further study will provide more insightful information from a clinical and translational viewpoint to use CTCs for cancer early diagnosis or prediction of tumor recurrence and investigation of tumor progression and metastasis as well.

Key words: Cancer stem cells, circulating tumor cells, epithelial-mesenchymal transition, gastrointestinal cancer, tumor progression and metastasis

\section{Introduction}

Tumor recurrence often occurs in patients with gastrointestinal (GI) cancers, even after a curative resection, which may be because undetectable tumor cells depositor enter into the blood stream at the time of operation. In some cases, tumor recurs despite adjuvant chemotherapy after curative surgery suggesting that chemotherapy failed to eradicate all cancer cells that persist after curative surgery. Thus, tumor cells could be disseminated before surgery. The concept of the circulating tumor cells (CTCs) has been, therefore, established and indicates that tumor cells are in blood stream, which will facilitate tumor progression and metastasis although detection of CTCs in peripheral blood was described more than a century ago. ${ }^{[1]}$ Recent advance on research of CTCs largely contributed to diagnosis and treatment of GI cancers. However, the clinical relevance of CTC detection in GI cancers is still the subject of controversies, and their biology is poorly understood.

\begin{tabular}{|l|l|}
\hline \multicolumn{2}{|c|}{ Access this article online } \\
\hline Quick Response Code: & Website: \\
\hline & www.jcmtjournal.com \\
\cline { 2 - 2 } & \\
\hline
\end{tabular}

Indeed, detection of CTCs becomes a promising means to early diagnosis and prediction of prognosis and tumor recurrence for several types of human cancer. ${ }^{[2-5]}$ Furthermore, the study of CTCs could also elucidate the molecular biological profile of CTC and lead to better understanding of cancer metastasis. To date, standard procedures of CTC detection have to be established, and the clinical relevance should be confirmed by a large-scale clinical study. In this review, we updated and discussed recent progress regarding CTCs in GI cancer. These new data could improve our understanding of the mechanisms of cancer progression and metastasis as well as therapy resistance. This information may also lead to the development of novel clinical targets and improve the clinical management of GI cancer.

This is an open access article distributed under the terms of the Creative Commons Attribution-NonCommercial-ShareAlike 3.0 License, which allows others to remix, tweak, and build upon the work non-commercially, as long as the author is credited and the new creations are licensed under the identical terms.

For reprints contact: reprints@ @medknow.com

How to cite this article: Iwatsuki M, Kurashige J, Ishimoto T, Kosumi K, Baba Y, Sakamoto Y, Miyamoto Y, Yoshida N, Watanabe M, Baba H. The clinical significance of circulating tumor cells in gastrointestinal cancer. J Cancer Metastasis Treat 2015;1:130-7.

Received: 13-07-2015; Accepted: 18-08-2015. 


\section{Methodology in Detection of Circulating Tumor Cells}

In general, methodology in the detection of CTCs consists of two steps, that is, enrichment and detection process. The enrichment process is required because of the rarity of CTCs in peripheral circulation (one CTC per $1 \times 10^{6}$ to $1 \times 10^{7}$ mononuclear cells). To enrich CTCs from blood mononuclear cells, density gradient centrifugation (Ficoll-Hypaque or OncoQuick separation), immunomagnetic or size filtration procedures are used. ${ }^{[6,7]}$ After enrichment, the identification of CTCs is then performed. For identification techniques, nucleic acid methods and cytometric methods are usually used. Recently, the development of molecular techniques can make molecular and genetic analysis of CTCs after enrichment and identification of CTCs, leading to developing CTC characterization.

\section{Enrichment Techniques}

\section{Cell morphologic-based enrichment}

Isolation of CTCs using the size of epithelial tumors is based on the size of tumor cells without functional modification and complex enrichment procedures. It is usual to utilize $5-8 \mu \mathrm{m}$ probe filters to enable and to separate small leukocytes from the large epithelial cell and the isolation sensitivity threshold is approximately one tumor cell per milliliter. ${ }^{[8,9]}$ These techniques have a valuable advantage in isolation of CTCs without damaging cells and enable further immunocytochemical or immunofluorescence evaluation of CTCs. Although it is easily handled and cheap, it is considered to be not highly sensitive and poorly specific.

Furthermore, density gradient separation using Ficoll-Hypaque is an alternative technique to separate CTCs and mononuclear cells from other blood cells and granulocytes. However, Ficoll-Hypaque can be toxic to CTCs. CTCs can also be easily to lose due to the migration of cells to the plasma layer. OnkoQuick was developed to avoid the cross-contamination of different layers, resulting in higher recovery rate of CTCs. ${ }^{[10,11]}$ Recently, RosetteSep $^{\mathrm{TM}}$ (Stem Cell Technologies, Vancouver, British Columbia, Canada) developed a novel method based negative selection to improve the specificity of standard gradient separation. ${ }^{[12,13]}$

\section{Immunomagnetic circulating tumor cell enrichment}

The immunomagnetic CTC enrichment technique is a magnetic bead-based separation method. To date, there have been two methods to identify CTCs expressing targeting-specific biomarkers. One is using the epithelial cell-specific marker, e.g. epithelial cell adhesion molecule (EpCAM) or cytokeratin (CK) expressed on the surface of tumor cells from epithelial origin. Another is using the tumor-specific markers, such as $\alpha$-fetoprotein,
Her2-neu, or carcinoembryonic antigen (CEA) expressed on a particular type of cancer cells. Immunomagnetic isolation technique utilizes monoclonal antibodies that are labeled magnetic microbeads and separates CTCs from the leukocytes background by magnetic force. To separate leukocytes, the negative selection is performed using an anti-CD45 antibody recognizing surface marker of leukocytes. Based on this technique, the Magnetic Activated Cell Sorting System (MACS ${ }^{\mathrm{TM}}$ Miltenyi Biotec, Bergisch Gladbach, Nordrhein-Westfalen, Germany) is a useful technology for detecting and analyzing CTCs because it avoids cell lysis and enables cell count by immunocytochemistry and immunofluorescence assay. ${ }^{[14]}$ CellSearch System ${ }^{\mathrm{TM}}$ (Veridex, Warren, NJ) approved by the US Food and Drug Administration (FDA) is a semi-automated analyzer enriching the CTCs with ferrofluid nanoparticles coated with anti-EpCAM antibodies. This system is proved to be useful for detecting and analyzing CTCs with patients with breast, colorectal and prostate cancer in the clinic. ${ }^{[15]}$ However, Alunni-Fabbroni and Sandri argued that this technology has two possible limitations, that is, there is no "universal marker" available for each type of tumor, while epithelial marker (EpCAM) could be down-regulated in epithelial tumor cells after tumor cells undergo epithelial-mesenchymal transition (EMT). ${ }^{[16]}$ Thus, this method could only detect selected CTCs. ${ }^{[17,18]}$

\section{Enrichment Techniques}

\section{Nucleic acid-based analysis}

Reverse transcriptase polymerase chain reaction (RT-PCR) based techniques can increase the specificity of the molecular methods to discriminate between the higher levels of molecular changes in cancer patients and the low background level in normal cells. Expressions of epithelial or tumor-specific markers are detected using RT-PCR to evaluate and identify CTCs. Nowadays, multiplex RT-PCR approach has been established to screen at the same time more than one single biomarker. Furthermore, quantitative RT-PCR improves the specificity of detection for CTCs by defining a cut-off value for biomarker expression. However, there are some limitations of this method: (1) contamination of non-malignant epithelial cells such as skin cells; (2) false positive due to unspecific markers; and (3) amplification of cell-free nucleic acids. Therefore, it is essential to select the appropriate marker that is expressed specifically by tumor cells to boost the specificity and reliability of CTC detection.

\section{Cytometric-based analysis}

Cytometric-based technique can isolate and count CTCs using monoclonal antibodies against various antigens. To detect CTCs, CK and EpCAM are most commonly used. It enables to keep CTCs intact during analysis because cell lysis is not necessary. Furthermore, this technique provides information of high statistical 
precision and subpopulation quantification with high specificity due to simultaneous analysis using multiple parameters. However, in contrast to RT-PCR technique, the disadvantage of this technique has a lower sensitivity.

Fiber-optic Array Scanning Technology, a rapid and accurate CTC location cytometric system, is a scanning technology characterized by a large field of view. ${ }^{[19]}$ It allows analyzing large volumes of samples without any purification step and minimizing the risk of cell loss. Additional scanning systems such as ACIS (Automated Cellular Imaging System, DAKO, Spatial Technology, USA) and ARIOL (Applied Imaging Corp, Wetzlar, Germany) are available on the market.

\section{Recent Advances in Detection of Circulating Tumor Cells}

As discussed above, the detection of CTCs is involved in two steps of enrichment and identification; thus, the development of automated techniques could offer at the same time enrichment, staining and scanning of the samples. The Cell Search System ${ }^{\circledR}$ enriches the CTCs with ferrofluid nanoparticles coated with anti-EpCAM antibody. The enriched EpCAM+ population is stained with phycoerythrin-conjugated antibodies against CK-8, -18 and -19 with allophycocyanin-conjugated antibodies specific for leukocytes (anti-CD45 antibody) and with the nuclear dye 4', 6-diamino-2-phenylidole (DAPI) for the nucleic acids staining. The $\mathrm{CK}^{+} / \mathrm{DAPI}^{+} / \mathrm{CD} 45^{-}$cells are then counted as CTCs using CellSpotter analyzer (Veridex, Warren, NJ), a four-color semi-automated fluorescent microscope. ${ }^{[20]}$ More recently, CTC-chip based on a microfluidic platform has also developed to isolate a high rate of CTCs. ${ }^{[21]}$ CTC-chip consists of an array of 78,000 microspots coated with anti-EpCAM antibodies. Whole blood is pumped through this chip, and EpCAM+ cells are captured and detected by cameras identifying their morphology, viability and the expressions of tumor markers. ${ }^{[14]}$ However, the relevance of this technology in clinical setting remains unclear and clinical validation study is required. Finally, based on enzyme-linked immunospot assay technology, epithelial immunospot (EPISPOT) assay can identify CTCs by detecting specific CTC-secreted proteins (CK, mucin or prostate specific antigen). ${ }^{[22,23]}$ EPISPOT makes it possible to detect the only viable CTCs because dying CTCs are unable to secrete an adequate amount of proteins to be detected. Sensitivity of EPISPOT is superior to ELISA assay in a two-order magnitude while detecting the release of CK-19 from tumor cells. ${ }^{[24]}$

\section{Recent Development of Molecular and Genetic Characterization of Circulating Tumor Cells}

The next desirable step is to elucidate the molecular and genetic characterization of CTCs after enrichment and isolation of CTCs. This step may help us to comprehend the mechanism of cancer metastasis, leading to the development of treatments of tumor metastasis. However, the molecular and genetic characteristics of CTCs are not fully clarified when compared with corresponding tumors in GI cancer. The molecular and genetic characteristics of CTCs are usually analyzed by PCR-based methods, fluorescent in situ hybridization (FISH) or comparative genomic hybridization (CGH). There have been no reports about CTCs characterization analyzed by FISH and $\mathrm{CGH}$ in gastric cancer, whereas abnormal copy number alteration was detected in CTCs from patients with metastatic prostate cancer. ${ }^{[25-27]}$ Using PCR-based methods, conventional detection system with epithelial markers such as CEA and $\mathrm{CK}$ has been previously performed to show the clinical significance of CTCs in gastric cancer. ${ }^{[28-32]}$ However, Mimori et al. ${ }^{[33]}$ showed in a large-scale study that CTCs circulate even in early stages of the disease indicating that the simultaneous presence of CTC and VEGFR-1 expression is clinically significant for disease progression. It is also well known that there is discordance of expression profile between CTCs and primary tumor, and several markers for regulating metastasis and prognosis have been determined by PCR-based methods. ${ }^{[34-37]}$ Furthermore, a comprehensive molecular profiling using the cDNA microarray was performed to identify novel genes to predict gastric cancer metastasis, recurrence and prognosis, suggesting that expression of MT1-MMP in peripheral blood identified by the cDNA microarray technique in gastric cancer was a powerful indicator of distant metastasis, especially for peritoneal dissemination. ${ }^{[38]}$ van de Stolpe et $a{ }^{[39]}$ reported that CTCs were heterogeneous and differed among different cancer types. In addition to differences across cancer types, CTCs have heterogeneity within the same patient. Although the heterogeneity of primary tumors has been known, Klein et al. showed that early disseminated cancer cells are genomically very unstable, as well as the primary tumor. ${ }^{[40]}$ In this case, gastric cancer is well known to have histological heterogeneity in primary lesion. Various histological types and differentiation of gastric cancer cells are frequently observed in the same specimens. ${ }^{[41]}$ Therefore, histological heterogeneity may make it difficult to the molecular and genetic characterization of CTCs in GI cancer.

\section{Clinical Relevance of Circulating Tumor Cells in Gastrointestinal Cancer}

To date, there are a number of methodologies in the detection of CTCs and the clinical relevance of GI cancer have been reported. In clinical setting, the detection of CTC is expected to be useful in early diagnosis of cancer, monitoring of treatment responses and disease progression. In the following, we summarized a comprehensive update of the studies with more than 50 patients or with an outcome analysis and discussed their clinical implications in selected GI cancers.

\section{Esophageal cancer}

There are only a few studies of esophageal cancer available as compared to gastric and colorectal cancers 
[Table 1]. In esophageal cancer, RT-PCR was the main technique to detect CTCs in previous studies. ${ }^{[22-45]}$ As for available molecular markers, CEA and SCC are useful predictive markers for tumor recurrence and survival. Most recently, a large-scale of study using CellSearch System $^{\circledR}$, morphological technique are also reported. ${ }^{[46,47]}$ Matsushita et al. ${ }^{[46]}$ revealed that CTC detection by CellSearch System ${ }^{\circledR}$ was useful to evaluate the clinical efficacy of chemotherapy and chemoradiation therapy on esophageal cancer patients. Reeh et al. ${ }^{[4]}$ reported that patients with positive CTCs had significantly poorer overall survival and progression-free survival rate; therefore, preoperative CTC detection by CellSearch System $^{\circledR}$ was an independent prognostic indicator for patients with esophageal cancer. However, most of previously reported patients had esophageal squamous cell carcinoma. There are some differences of biological behaviors between esophageal squamous cell carcinoma and adenocarcinoma; therefore, further study of esophageal adenocarcinoma is needed.

\section{Gastric cancer}

A number of studies of CTC detection in patients with gastric cancer have been reported previously as summarized in Table 2. Although the several methodology of CTC detection including RT-PCR and CellSearch System ${ }^{\circledR}$ [Table 2], it remains unclear which is the best method and molecular marker for detection of CTCs in gastric cancer patients. Recently, various meta-analyses demonstrated that presence of CTCs was associated with poor prognosis and advanced clinicopathological factors. ${ }^{[48-50]}$ It has been reported that detection of CTCs in gastric cancer may be useful in early diagnosis and monitoring of treatment responses and prognosis. However, as for diagnosis, a recent meta-analysis showed that CTC detection alone cannot be recommended as a screening test for gastric cancer because of lower and inconsistent sensitivity estimates for CTC..$^{[51]}$ Furthermore, Mimori et al. ${ }^{[33]}$ showed that CTCs occurred in early stages of the disease, and CTC

Table 1: Clinical relevance of CTC in esophageal cancer

\begin{tabular}{lcclll}
\hline Author & Year & Case & Method & Molecuar marker & Clinical relevance \\
\hline Kaganoi & 2004 & 70 & RT-PCR & SCC & Prediction of recurrence \\
Setoyama & 2006 & 106 & RT-PCR & CEA & Prediction of recurrence \\
Liu & 2007 & 53 & RT-PCR & CEA & Prediction of recurrence \\
Hashimoto & 2008 & 147 & RT-PCR & CEA & Prediction of recurrence and prognosis \\
Cao & 2009 & 108 & RT-PCR & Survivin & Prediction of haematogenous recurrence and prognosis \\
Tanaka & 2010 & 244 & RT-PCR & CEA, SCC & Predictor for hematogenous and local recurrences \\
Yin & 2012 & 72 & RT-PCR & CEA, CK-19, Survivin & Clinical efficacy of RT \\
Matsushita & 2014 & 90 & CellSearch & EpCAM, CK-8, 18, 19 & Clinical efficacy of CT or CRT \\
Reeh & 2015 & $100^{*}$ & CellSearch & EpCAM, CK-8, 18, 19 & Prediction of recurrence and prognosis \\
\hline
\end{tabular}

*Esophageal adenocarcinoma is included. RT: Radiotherapy; CRT: Chemoradiation therapy

Table 2: Clinical relevance of CTC in gastric cancer

\begin{tabular}{lcclll}
\hline Author & Year & Case & Method & Molecuar marker & Clinical relevance \\
\hline Wu & 2006 & 64 & MAH & hTERT, CK-19, CEA, MUC1 & Associated with recurrence \\
Pituch-Noworolska & 2007 & 57 & ICC & CK-8, 18, 19 & No prognostic impact \\
Ito & 2010 & 65 & ICC & GFP, EpCAM, & Shorter OS \\
Majima & 2000 & 52 & RT-PCR & CK-19, 20 & Shorter OS \\
Miyazono & 2001 & 57 & RT-PCR & CEA & Associated with liver metastaisis, recurrence \\
Sumikura & 2003 & 106 & RT-PCR & CEA & Associated with recurrence \\
Illert & 2005 & 70 & RT-PCR & CK-20 & Shorter OS \\
Ikeguchi & 2005 & 59 & RT-PCR & CEA & No association with recurrence \\
Uen & 2006 & 52 & RT-PCR & MUC1, c-Met & Shorter OS \\
Koga & 2008 & 101 & RT-PCR & CK-18, 19, 20 & Shorter OS (CK-19 is better) \\
Yie & 2008 & 55 & RT-PCR, ELISA & Survivin & Predictive marker for DFS \\
Mimori & 2008 & 810 & RT-PCR & CK-7,19, 20, VEGFR1 & Associated with hematogenous metatasis \\
Bertazza & 2009 & 70 & RT-PCR & Survivin & Predictive marker for OS \\
Qiu & 2010 & 123 & RT-PCR & CEA & Predictive marker for DFS \\
Arigami & 2010 & 94 & RT-PCR & B7-H3 & Shorter OS \\
Arigami & 2011 & 95 & RT-PCR & B7-H4 & Shorter OS \\
Cao & 2011 & 98 & RT-PCR, ELISA & Survivin & Predictive marker for DFS \\
Arigami & 2013 & 93 & RT-PCR & STC2 & Shorter OS \\
Matsusaka & 2010 & 52 & CellSearch & EpCAM, CK-8, 18, 19 & Predictive marker for PFS (CTC level after Cx) \\
Uenosono & 2013 & 148 & CellSearch & EpCAM, CK-8, 18, 19 & Predictive marker for PFS and OS \\
\hline MAH: & &
\end{tabular}

MAH: Membrane-array hybrudization; ICC: Immunocytochemistry; hTERT: Human Telomerase reverse transcriptase;

ELISA: Enzyme-Linked ImmunoSorbentAssay; DFS: Disease free survival; OS: Overall survival; PFS: Progression free survival 
alone can not be a predictor of cancer metastasis in a large-scale study. This study also revealed that elevated expression of VEGFR-1 facilitated the establishment of hematogenous metastases of gastric cancer and that the simultaneous presence of CTC and VEGFR-1 expression at premetastatic sites was clinically significant in disease progression.

\section{Colorectal cancer}

To date, there are a large number of studies of CTC detection in colorectal cancer as compared to other GI cancers as summarized in Table 3. RT-PCR and the CellSearch System ${ }^{\circledR}$ have been mainly reported methods to detect CTC in colorectal cancer and data showed that CTCs were associated recurrence and overall survival of patients. For example, Cohen et al. ${ }^{[2]}$ revealed that the number of CTCs detected by the CellSearch System ${ }^{\circledR}$ before and during treatment was an independent predictor of PFS and OS in 430 patients with metastatic colorectal cancer in a prospective multicenter clinical trial. The CellSearch System ${ }^{\circledR}$ using in colorectal cancer was the first CTC detection system that was approved by US FDA. ${ }^{[2]}$ Furthermore, a previous meta-analysis reported the aprognostic significance of CTC detected by the CellSearch System ${ }^{\circledR}$ has been reported. ${ }^{[48]}$ Eleven studies including 1,847 colorectal cancer patients were analyzed in this study and the presence of CTCs was significantly associated with overall and progression-free survival as reported by the previous meta-analysis. ${ }^{[52]}$ In a previous prospective study of non-metastatic colorectal cancer, preoperative CTC detection was a strong and independent prognostic marker. ${ }^{[53]}$ The treatment response rate was significantly lower in CTC-positive patients than that of CTC negative patients at base line and during treatment. ${ }^{[23,54-57]}$ Another previous study demonstrated potentially clinical application in detection of KRAS mutational in CTCs for selecting metastatic colorectal cancer patients for cetuximab therapy. ${ }^{[58]}$ In addition, recent development of molecular and genetic characterization of single-CTC demonstrated that there was intra- and inter- heterogeneity of EGFR expression and genetic alterations of EGFR, KRAS and PIK3CA,

Table 3: Clinical relevance of CTC in colorectal cancer

\begin{tabular}{|c|c|c|c|c|c|}
\hline$\overline{\text { Author }}$ & Year & Case & Method & Molecuar marker & Clinical relevance \\
\hline Wong & 2009 & 132 & ICC & CK-20 & Predictive marker for OS \\
\hline Tanigich & 2000 & 53 & RT-PCR & CEA & Predictive marker for DFS \\
\hline Yamagichi & 2000 & 52 & RT-PCR & CK-20, CEA & Shorter OS \\
\hline Hardingham & 2000 & 94 & RT-PCR & CK-19, 20, MUC2 & Shorter DFS \\
\hline Bessa & 2001 & 68 & RT-PCR & CEA & No prognostic impact \\
\hline Ito & 2002 & 99 & RT-PCR & CEA & Shorter DFS \\
\hline Bessa & 2003 & $66^{*}$ & RT-PCR & CEA & No prognostic impact \\
\hline Sadahiro & 2005 & 93 & RT-PCR & CEA & No prognostic impact \\
\hline Koch & 2006 & 90 & RT-PCR & CK-20 & Shorter DFS \\
\hline Douard & 2006 & 121 & RT-PCR & CK-20, CGM2 & No prognostic impact \\
\hline Iinuma & 2006 & 167 & RT-PCR & CK-20, CEA & Shorter DFS and OS \\
\hline Katsumata & 2006 & 57 & RT-PCR & CK-20 & Strong relation to $\mathrm{LN}$ metastais and $\mathrm{OS}$ \\
\hline Allen-Mersh & 2007 & $113^{*}$ & RT-PCR & CK-20, CEA & Shorter DFS \\
\hline Wang & 2007 & $157^{*}$ & RT-PCR** & CK-19, 20, CEA, hTERT & Shorter DFS \\
\hline Uen & 2007 & 194 & RT-PCR** & CK-19, 20, CEA, hTERT & Shorter DFS \\
\hline Sadahiro & 2007 & $200^{*}$ & RT-PCR & CEA & Shorter DFS \\
\hline Uen & 2007 & $438^{*}$ & RT-PCR & CK-19, 20, CEA, hTERT & Shorter DFS \\
\hline Yie & 2008 & 86 & RT-PCR, ELISA & Survivin & Predictive marker for DFS \\
\hline $\mathrm{Lu}$ & 2011 & $141 *$ & RT-PCR** & CK-19, 20, CEA, hTERT & Shorter DFS and OS \\
\hline Iinuma & 2011 & 735 & RT-PCR & CK-19, 20, CEA, hTERT & Shorter DFS and OS \\
\hline Pilati & 2012 & 50 & RT-PCR & $\begin{array}{l}\text { CK-19, 20, CEA, CD133, } \\
\text { VEGF, EGFR, Survivin }\end{array}$ & Predictive marker for OS (CD133 CTC) \\
\hline Cohen & 2008 & 430 & CellSearch & EpCAM, CK-8, 18, 19 & Predictive marker for $\mathrm{OS}(\mathrm{CTC} \geq 3)$ \\
\hline Matsusaka & 2011 & 64 & CellSearch & EpCAM, CK-8, 18, 19 & Predictive marker for PFS and OS (CTC level after Cx) \\
\hline Tol & 2010 & 467 & CellSearch & EpCAM, CK-8, 18, 19 & Predictive marker for PFS and OS (CTC level before Cx) \\
\hline Sastre & 2012 & 180 & CellSearch & EpCAM, CK-8, 18, 19 & Predictive marker for PFS and OS (CTC level before Cx) \\
\hline Aggarwal & 2013 & 209 & CellSearch & EpCAM, CK-8, 18, 19 & Predictive marker for OS (CTC level before $\mathrm{Cx}$ ) \\
\hline Gazzaniga & 2013 & 119 & CellSearch & EpCAM, CK-8, 18, 19 & Predictive marker for $\mathrm{OS}(\mathrm{CTC} \geq 1)$ \\
\hline Kuboki & 2013 & 63 & CellSearch & EpCAM, CK-8, 18, 19 & Shorter DFS and OS \\
\hline Sotelo & 2015 & 472 & CellSearch & EpCAM, CK-8, 18, 19 & No prognostic impact (stage III) \\
\hline Seeberg & 2015 & 194 & CellSearch & EpCAM, CK-8, 18, 19 & Predict nonresectability and impaired survival \\
\hline
\end{tabular}

*Post-operative mesuament. **Membrane array. ICC: Immunocytochemistry; ELISA: Enzyme-Linked ImmunoSorbent Assay; hTERT: Human Telomerase reverse transcriptase; LN: Lymphnode metastasis; DFS: Disease free survival; OS: Overall survival; PFS: Progression free survival; Cx: Chemotherapy 
which possibly explained the variable response rates to EGFR inhibition in patients with colorectal cancer. ${ }^{[59]}$ Therefore, the information on the molecular status of CTCs might be useful for stratification of molecular-directed therapy.

\section{Future Perspectives}

\section{Epithelial-mesenchymal transition}

There are two main approaches in the detection of CTCs, that is, immunological assays using monoclonal antibodies and PCR-based molecular assays, exploiting tissue-specific transcripts. ${ }^{[60]}$ Immunocytochemical detection of epithelial or tumor-associated antigens is widely accepted. ${ }^{[61]}$ Recent studies have shown that EMT plays a critical role in cancer progression and metastasis in epithelial malignancies including gastric cancer. ${ }^{[62]}$ Our previous study implied that vimentin-positive tumor cells were able to survive in the peripheral circulation and in the bone marrow and that vimentin-positive cancer cells that invade intratumoral vessels must have undergone mesenchymal transition. We assume that not all detected CTCs but rather only a few, which have undergone EMT could give rise to tumor metastasis or recurrence. ${ }^{[17]}$ Most recently, $\mathrm{Wu}$ et al. ${ }^{[63]}$ reported that mesenchymal CTCs classified using EMT markers were more commonly found in patients in metastatic stages of the disease in different types of human cancers. Therefore, it is possible that conventional detection system using epithelial markers fail to detect that population of CTCs.

\section{Cancer stem cell}

Furthermore, the concept of rare subpopulations of cancer stem cells (CSCs) has created a novel focus in cancer research but arises a question whether CTCs have CSC property. It is expected that CTC with CSC property may be disseminated from the primary tumor lesion to a distant metastatic site. This hypothesis is supported by the similarities between the properties of CTCs and CSC and suggests that the founder cells of metastases arise from the CTC population. It has been reported that stem cell markers are frequently overexpressed in the CTCs of patients with metastatic breast cancer, and the most CTCs have stem cell phenotypes that are non-proliferating and resistant to chemotherapy. For example, Iinuma et al. ${ }^{[64]}$ revealed that multi genetic markers of CSC, CEA/CK/CD133 in peripheral blood samples could be a useful predictor for recurrence and prognosis. Pilati et al. ${ }^{[65]}$ reported that CD133-positive CTCs might represent a suitable prognostic marker to stratify the risk of patients who undergo liver resection for CRC metastasis.

\section{Conclusion}

An increasing number of studies have shown that CTC is associated with GI cancer progression, metastasis and resistance to pharmacotherapy. However, the clinical evidence supporting the role of CTC in cancer progression still remains inconclusive. Therefore, further analysis and clinical trials are required to achieve clinical utility of CTC detection in GI cancers.

\section{Acknowledgments}

This work was supported in part by the following grants and foundations: Japan Society for the Promotion of Science (JSPS) Grant-in-Aid for Scientific Research; Grant Numbers: 23791550.

\section{Financial support and sponsorship}

This work was supported in part by the following grants and foundations: Japan Society for the Promotion of Science (JSPS) Grant-in-Aid for Scientific Research; Grant Numbers 23791550.

\section{Conflicts of interest}

There are no conflicts of interest.

\section{References}

1. Engell HC. Cancer cells in the circulating blood; a clinical study on the occurrence of cancer cells in the peripheral blood and in venous blood draining the tumour area at operation. Ugeskr Laeger 1955;117:822-3.

2. Cohen SJ, Punt CJ, Iannotti N, Saidman BH, Sabbath KD, Gabrail NY, Picus J, Morse M, Mitchell E, Miller MC, Doyle GV, Tissing H, Terstappen LW, Meropol NJ. Relationship of circulating tumor cells to tumor response, progression-free survival, and overall survival in patients with metastatic colorectal cancer. J Clin Oncol 2008;26:3213-21.

3. Krebs MG, Sloane R, Priest L, Lancashire L, Hou JM, Greystoke A, Ward TH, Ferraldeschi R, Hughes A, Clack G, Ranson M, Dive C, Blackhall FH. Evaluation and prognostic significance of circulating tumor cells in patients with non-small-cell lung cancer. J Clin Oncol 2011;29:1556-63.

4. Scher HI, Jia X, de Bono JS, Fleisher M, Pienta KJ, Raghavan D, Heller G. Circulating tumour cells as prognostic markers in progressive, castration-resistant prostate cancer: a reanalysis of IMMC38 trial data. Lancet Oncol 2009;10:233-9.

5. Zhang L, Riethdorf S, Wu G, Wang T, Yang K, Peng G, Liu J, Pantel K. Meta-analysis of the prognostic value of circulating tumor cells in breast cancer. Clin Cancer Res 2012;18:5701-10.

6. Weitz J, Kienle P, Lacroix J, Willeke F, Benner A, Lehnert T, Herfarth C, von Knebel Doeberitz M. Dissemination of tumor cells in patients undergoing surgery for colorectal cancer. Clin Cancer Res 1998;4:343-8.

7. Rosenberg R, Gertler R, Friederichs J, Fuehrer K, Dahm M, Phelps R, Thorban S, Nekarda H, Siewert JR. Comparison of two density gradient centrifugation systems for the enrichment of disseminated tumor cells in blood. Cytometry 2002;49:150-8

8. Tan SJ, Yobas L, Lee GY, Ong CN, Lim CT. Microdevice for the isolation and enumeration of cancer cells from blood. Biomed Microdevices 2009;11:883-92.

9. Vona G, Sabile A, Louha M, Sitruk V, Romana S, Schutze K, Capron F, Franco D, Pazzagli M, Vekemans M, Lacour B, Brechot C, Paterlini-Brechot P. Isolation by size of epithelial tumor cells: a new method for the immunomorphological and molecular characterization of circulatingtumor cells. $\mathrm{Am} J$ Pathol 2000;156:57-63.

10. Gertler R, Rosenberg R, Fuehrer K, Dahm M, Nekarda H, 
Siewert JR. Detection of circulating tumor cells in blood using an optimized density gradient centrifugation. Recent Results Cancer Res 2003;162:149-55.

11. Muller V, Stahmann N, Riethdorf S, Rau T, Zabel T, Goetz A, Janicke F, Pantel K. Circulating tumor cells in breast cancer: correlation to bone marrow micrometastases, heterogeneous response to systemic therapy and low proliferative activity. Clin Cancer Res 2005;11:3678-85.

12. Busch R, Cesar D, Higuera-Alhino D, Gee T, Hellerstein MK, McCune JM. Isolation of peripheral blood CD4(+) T cells using RosetteSep and MACS for studies of DNA turnover by deuterium labeling. J Immunol Methods 2004;286:97-109.

13. Hayes GM, Busch R, Voogt J, Siah IM, Gee TA, Hellerstein MK, Chiorazzi N, Rai KR, Murphy EJ. Isolation of malignant $\mathrm{B}$ cells from patients with chronic lymphocytic leukemia (CLL) for analysis of cell proliferation: validation of a simplified method suitable for multi-center clinical studies. Leuk Res 2010;34:809-15.

14. McNiece I, Briddell R, Stoney G, Kern B, Zilm K, Recktenwald D, Miltenyi S. Large-scale isolation of CD34+ cells using the amgen cell selection device results in high levels of purity and recovery. J Hematother 1997;6:5-11.

15. Negin BP, Cohen SJ. Circulating tumor cells in colorectal cancer: past, present, and future challenges. Curr Treat Options Oncol 2010;11:1-13.

16. Alunni-Fabbroni M, Sandri MT. Circulating tumour cells in clinical practice: methods of detection and possible characterization. Methods 2010;50:289-97.

17. Iwatsuki M, Mimori K, Fukagawa T, Ishii H, Yokobori T, Sasako M, Baba H, Mori M. The clinical significance of vimentin-expressing gastric cancer cells in bone marrow. Ann Surg Oncol 2010;17:2526-33.

18. Iwatsuki M, Mimori $\mathrm{K}$, Yokobori $\mathrm{T}$, Ishi $\mathrm{H}$, Beppu $\mathrm{T}$, Nakamori S, Baba H, Mori M. Epithelial-mesenchymal transition in cancer development and its clinical significance. Cancer Sci 2010;101:293-9.

19. Krivacic RT, Ladanyi A, Curry DN, Hsieh HB, Kuhn P, Bergsrud DE, Kepros JF, Barbera T, Ho MY, Chen LB, Lerner RA, Bruce RH. A rare-cell detector for cancer. Proc Natl Acad Sci U S A 2004;101:10501-4.

20. Allard WJ, Matera J, Miller MC, Repollet M, Connelly MC, Rao C, Tibbe AG, Uhr JW, Terstappen LW. Tumor cells circulate in the peripheral blood of all major carcinomas but not in healthy subjects or patients with nonmalignant diseases. Clin Cancer Res 2004;10:6897-904.

21. Nagrath S, Sequist LV, Maheswaran S, Bell DW, Irimia D, Ulkus L, Smith MR, Kwak EL, Digumarthy S, Muzikansky A, Ryan P, Balis UJ, Tompkins RG, Haber DA, Toner M. Isolation of rare circulating tumour cells in cancer patients by microchip technology. Nature 2007;450:1235-9.

22. Alix-Panabieres C, Brouillet JP, Fabbro M, Yssel H, Rousset T, Maudelonde T, Choquet-Kastylevsky G, Vendrell JP. Characterization and enumeration of cells secreting tumor markers in the peripheral blood of breast cancer patients. J Immunol Methods 2005;299:177-88.

23. Alix-Panabieres C, Vendrell JP, Pelle O, Rebillard X, Riethdorf S, Muller V, Fabbro M, Pantel K. Detection and characterization of putative metastatic precursor cells in cancer patients. Clin Chem 2007;53:537-9.

24. Alix-Panabieres C, Vendrell JP, Slijper M, Pelle O, Barbotte E, Mercier G, Jacot W, Fabbro M, Pantel K. Full-length cytokeratin-19 is released by human tumor cells: a potential role in metastatic progression of breast cancer. Breast Cancer Res 2009;11:R39.

25. Attard G, Swennenhuis JF, Olmos D, Reid AH, Vickers E,
A'Hern R, Levink R, Coumans F, Moreira J, Riisnaes R, Oommen NB, Hawche G, Jameson C, Thompson E, Sipkema R, Carden CP, Parker C, Dearnaley D, Kaye SB, Cooper CS, Molina A, Cox ME, Terstappen LW, de Bono JS. Characterization of ERG, AR and PTEN gene status in circulating tumor cells from patients with castration-resistant prostate cancer. Cancer Res 2009;69:2912-8.

26. Leversha MA, Han J, Asgari Z, Danila DC, Lin O, Gonzalez-Espinoza R, Anand A, Lilja H, Heller G, Fleisher M, Scher HI. Fluorescence in situ hybridization analysis of circulating tumor cells in metastatic prostate cancer. Clin Cancer Res 2009;15:2091-7.

27. Paris PL, Kobayashi Y, Zhao Q, Zeng W, Sridharan S, Fan T, Adler HL, Yera ER, Zarrabi MH, Zucker S, Simko J, Chen WT, Rosenberg J. Functional phenotyping and genotyping of circulating tumor cells from patients with castration resistant prostate cancer. Cancer Lett 2009;277:164-73.

28. Chen XM, Chen GY, Wang ZR, Zhu FS, Wang XL, Zhang X. Detection of micrometastasis of gastric carcinoma in peripheral blood circulation. World J Gastroenterol 2004;10:804-8.

29. Koga T, Tokunaga E, Sumiyoshi Y, Oki E, Oda S, Takahashi I, Kakeji Y, Baba H, Maehara Y. Detection of circulating gastric cancer cells in peripheral blood using real time quantitative RT-PCR. Hepatogastroenterology 2008;55:1131-5.

30. Pituch-Noworolska A, Kolodziejczyk P, Kulig J, Drabik G, Szczepanik A, Czupryna A, Popiela T, Zembala M. Circulating tumour cells and survival of patients with gastric cancer. Anticancer Res 2007;27:635-40.

31. Soeth E, Vogel I, Roder C, Juhl H, Marxsen J, Kruger U, Henne-Bruns D, Kremer B, Kalthoff H. Comparative analysis of bone marrow and venous blood isolates from gastrointestinal cancer patients for the detection of disseminated tumor cells using reverse transcription PCR. Cancer Res 1997;57:3106-10.

32. $\mathrm{Wu} \mathrm{CH}$, Lin SR, Hsieh JS, Chen FM, Lu CY, Yu FJ, Cheng TL, Huang TJ, Huang SY, Wang JY. Molecular detection of disseminated tumor cells in the peripheral blood of patients with gastric cancer: evaluation of their prognostic significance. Dis Markers 2006;22:103-9.

33. Mimori K, Fukagawa T, Kosaka Y, Kita Y, Ishikawa K, Etoh T, Iinuma H, Sasako M, Mori M. Hematogenous metastasis in gastric cancer requires isolated tumor cells and expression of vascular endothelial growth factor receptor-1. Clin Cancer Res 2008;14:2609-16.

34. Arigami T, Uenosono $\mathrm{Y}$, Hirata $\mathrm{M}$, Yanagita $\mathrm{S}$, Ishigami $\mathrm{S}$, Natsugoe S. B7-H3 expression in gastric cancer: a novel molecular blood marker for detecting circulating tumor cells. Cancer Sci 2011;102:1019-24.

35. Cao W, Yang W, Li H, Lou G, Jiang J, Geng M, Xi W, Ren R, Qu Q, Jin X, Zhu Y, Jin Y. Using detection of survivin-expressing circulating tumor cells in peripheral blood to predict tumor recurrence following curative resection of gastric cancer. J Surg Oncol 2011;103:110-5.

36. Kita Y, Fukagawa T, Mimori K, Kosaka Y, Ishikawa K, Aikou T, Natsugoe S, Sasako M, Mori M. Expression of uPAR mRNA in peripheral blood is a favourite marker for metastasis in gastric cancer cases. Br J Cancer 2009;100:153-9.

37. Kosaka Y, Mimori K, Fukagawa T, Ishikawa K, Etoh T, Katai H, Sano T, Watanabe M, Sasako M, Mori M. Identification of the high-risk group for metastasis of gastric cancer cases by vascular endothelial growth factor receptor-1 overexpression in peripheral blood. $\mathrm{Br} J$ Cancer 2007;96:1723-8.

38. Mimori K, Fukagawa T, Kosaka Y, Ishikawa K, Iwatsuki M, Yokobori T, Hirasaki S, Takatsuno Y, Sakashita H, Ishii H, Sasako M, Mori M. A large-scale study of MT1-MMP as a 
marker for isolated tumor cells in peripheral blood and bone marrow in gastric cancer cases. Ann Surg Oncol 2008;15:2934-42.

39. van de Stolpe A, Pantel K, Sleijfer S, Terstappen LW, den Toonder JM. Circulating tumor cell isolation and diagnostics: toward routine clinical use. Cancer Res 2011;71:5955-60.

40. Klein CA, Blankenstein TJ, Schmidt-Kittler O, Petronio M, Polzer B, Stoecklein NH, Riethmuller G. Genetic heterogeneity of single disseminated tumour cells in minimal residual cancer. Lancet 2002;360:683-9.

41. Ikeda Y, Mori M, Kamakura T, Haraguchi Y, Saku M, Sugimachi K. Increased incidence of undifferentiated type of gastric cancer with tumor progression in 912 patients with early gastric cancer and 1245 with advanced gastric cancer. Cancer 1994;73:2459-63.

42. Kaganoi J, Shimada Y, Kano M, Okumura T, Watanabe G, Imamura M. Detection of circulating oesophageal squamous cancer cells in peripheral blood and its impact on prognosis. Br J Surg 2004;91:1055-60.

43. Liu Z, Jiang M, Zhao J, Ju H. Circulating tumor cells in perioperative esophageal cancer patients: quantitative assay system and potential clinical utility. Clin Cancer Res 2007;13:2992-7.

44. Setoyama T, Natsugoe S, Okumura H, Matsumoto M, Uchikado Y, Ishigami S, Owaki T, Takao S, Aikou T. Carcinoembryonic antigen messenger RNA expression in blood predicts recurrence in esophageal cancer. Clin Cancer Res 2006;12:5972-7.

45. Tanaka K, Yano M, Motoori M, Kishi K, Miyashiro I, Shingai T, Gotoh K, Noura S, Takahashi H, Ohue M, Yamada T, Ohigashi H, Yamamoto T, Yamasaki T, Doki Y, Ishikawa O. CEA-antigen and SCC-antigen mRNA expression in peripheral blood predict hematogenous recurrence after resection in patients with esophageal cancer. Ann Surg Oncol 2010;17:2779-86.

46. Matsushita D, Uenosono Y, Arigami T, Yanagita S, Nishizono Y, Hagihara T, Hirata M, Haraguchi N, Arima H, Kijima Y, Kurahara H, Maemura K, Okumura H, Ishigami S, Natsugoe S. Clinical significance of circulating tumor cells in peripheral blood of patients with esophageal squamous cell carcinoma. Ann Surg Oncol 2015. doi: 10.1245/s10434-015-4392-8.

47. Reeh M, Effenberger KE, Koenig AM, Riethdorf S, Eichstadt D, Vettorazzi E, Uzunoglu FG, Vashist YK, Izbicki JR, Pantel K, Bockhorn M. Circulating tumor cells as a biomarker for preoperative prognostic staging in patients with esophageal cancer. Ann Surg 2015;261:1124-30.

48. Huang X, Gao P, Song Y, Sun J, Chen X, Zhao J, Xu H, Wang Z. Meta-analysis of the prognostic value of circulating tumor cells detected with the CellSearch System in colorectal cancer. BMC Cancer 2015;15:202.

49. Wang S, Zheng G, Cheng B, Chen F, Wang Z, Chen Y, Wang Y, Xiong B. Circulating tumor cells (CTCs) detected by RT-PCR and its prognostic role in gastric cancer: a meta-analysis of published literature. PLoS One 2014;9:e99259.

50. Zhang ZY, Dai ZL, Yin XW, Li SH, Li SP, Ge HY, Meta-analysis shows that circulating tumor cells including circulating microRNAs are useful to predict the survival of patients with gastric cancer. BMC Cancer 2014;14:773.

51. Tang L, Zhao S, Liu W, Parchim NF, Huang J, Tang Y, Gan P, Zhong M. Diagnostic accuracy of circulating tumor cells detection in gastric cancer: systematic review and meta-analysis. BMC Cancer 2013;13:314.

52. Rahbari NN, Aigner M, Thorlund K, Mollberg N, Motschall E, Jensen K, Diener MK, Buchler MW, Koch M, Weitz J. Meta-analysis shows that detection of circulating tumor cells indicates poor prognosis in patients with colorectal cancer.
Gastroenterology 2010;138:1714-26.

53. Bork U, Rahbari NN, Scholch S, Reissfelder C, Kahlert C, Buchler MW, Weitz J, Koch M. Circulating tumour cells and outcome in non-metastatic colorectal cancer: a prospective study. Br J Cancer 2015;112:1306-13.

54. Aggarwal C, Meropol NJ, Punt CJ, Iannotti N, Saidman BH, Sabbath KD, Gabrail NY, Picus J, Morse MA, Mitchell E, Miller MC, Cohen SJ. Relationship among circulating tumor cells, CEA and overall survival in patients with metastatic colorectal cancer. Ann Oncol 2013;24:420-8.

55. Matsusaka S, Suenaga M, Mishima Y, Kuniyoshi R, Takagi K, Terui Y, Mizunuma N, Hatake K. Circulating tumor cells as a surrogate marker for determining response to chemotherapy in Japanese patients with metastatic colorectal cancer. Cancer Sci 2011;102:1188-92.

56. Sastre J, Maestro ML, Gomez-Espana A, Rivera F, Valladares M, Massuti B, Benavides M, Gallen M, Marcuello E, Abad A, Arrivi A, Fernandez-Martos C, Gonzalez E, Tabernero JM, Vidaurreta M, Aranda E, Diaz-Rubio E. Circulating tumor cell count is a prognostic factor in metastatic colorectal cancer patients receiving first-line chemotherapy plus bevacizumab: a Spanish Cooperative Group for the Treatment of Digestive Tumors study. Oncologist 2012;17:947-55.

57. Tol J, Koopman M, Miller MC, Tibbe A, Cats A, Creemers GJ, Vos AH, Nagtegaal ID, Terstappen LW, Punt CJ. Circulating tumour cells early predict progression-free and overall survival in advanced colorectal cancer patients treated with chemotherapy and targeted agents. Ann Oncol 2010;21:1006-12.

58. Yen LC, Yeh YS, Chen CW, Wang HM, Tsai HL, Lu CY, Chang YT, Chu KS, Lin SR, Wang JY. Detection of KRAS oncogene in peripheral blood as a predictor of the response to cetuximab plus chemotherapy in patients with metastatic colorectal cancer. Clin Cancer Res 2009;15:4508-13.

59. Gasch C, Bauernhofer T, Pichler M, Langer-Freitag S, Reeh M, Seifert AM, Mauermann O, Izbicki JR, Pantel K, Riethdorf S. Heterogeneity of epidermal growth factor receptor status and mutations of KRAS/PIK3CA in circulating tumor cells of patients with colorectal cancer. Clin Chem 2013;59:252-60.

60. Pantel K, Brakenhoff RH, Brandt B. Detection, clinical relevance and specific biological properties of disseminating tumour cells. Nat Rev Cancer 2008;8:329-40.

61. Braun S, Pantel K, Muller P, Janni W, Hepp F, Kentenich CR, Gastroph S, Wischnik A, Dimpfl T, Kindermann G, Riethmuller G, Schlimok G. Cytokeratin-positive cells in the bone marrow and survival of patients with stage I, II, or III breast cancer. $N$ Engl J Med 2000;342:525-33.

62. Yang J, Weinberg RA. Epithelial-mesenchymal transition: at the crossroads of development and tumor metastasis. Dev Cell 2008;14:818-29.

63. Wu S, Liu S, Liu Z, Huang J, Pu X, Li J, Yang D, Deng H, Yang $\mathrm{N}, \mathrm{Xu} \mathrm{J}$. Classification of circulating tumor cells by epithelial-mesenchymal transition markers. PLoS One 2015;10:e0123976.

64. Iinuma H, Watanabe $\mathrm{T}$, Mimori $\mathrm{K}$, Adachi M, Hayashi N, Tamura J, Matsuda K, Fukushima R, Okinaga K, Sasako M, Mori M. Clinical significance of circulating tumor cells, including cancer stem-like cells, in peripheral blood for recurrence and prognosis in patients with Dukes' stage B and C colorectal cancer. J Clin Oncol 2011;29:1547-55.

65. Pilati P, Mocellin S, Bertazza L, Galdi F, Briarava M, Mammano E, Tessari E, Zavagno G, Nitti D. Prognostic value of putative circulating cancer stem cells in patients undergoing hepatic resection for colorectal liver metastasis. Ann Surg Oncol 2012;19:402-8. 